УДК 581.135.51:582.929.4(571.1)

\title{
ИССЛЕДОВАНИЕ ХИМИЧЕСКОГО СОСТАВА ЭФИРНЫХ МАСЕЛ ORIGANUM VULGARE L. C РАЗЛИЧНОЙ ОКРАСКОЙ ЦВЕТКОВ
}

\author{
() М.А. Мяделеи ${ }^{1 *}$ О.Ю. Васильева ${ }^{1}$, Д.В. Домрачев ${ }^{2}$ \\ ${ }^{1}$ Центральный сибирский ботанический сад СО РАН, ул. Золотодолинская, \\ 101, Новосибирск, 630090 (Россия), e-mail: MarinaMyadelets@yandex.ru \\ ${ }^{2}$ Новосибирский институт органической химии им. Н.Н. Ворожцова СО РАН, \\ пр. акад. Лаврентьева, 9, Новосибирск, 630090 (Россия)
}

Методом хромато-масс-спектрометрии проведено сравнительное исследование химического состава эфирных масел Origanum vulgare L. с белыми и фиолетовыми цветками, произрастающих вблизи линии электропередач (ЛЭП). В составе масла $O$. vulgare с фиолетовыми цветками обнаружено 143 компонента (идентифицировано 67), с белыми 28 (идентифицировано 20). Процентное содержание общих для образцов компонентов зачастую в два раза выше в эфирном масле белой формы $O$. vulgare. Изученные образцы эфирных масел относятся к хемотипу, не содержащему фенольных соединений.

Ключевые слова: Origanum vulgare L., эфирное масло, хромато-масс-спектрометрия, электромагнитное излучение.

\section{Введение}

Origanum vulgare L. является одним из наиболее распространенных в научной и народной медицине лекарственных растений.

Одной из важных характеристик $O$. vulgare является эфирное масло, содержание и компонентный состав которого определялись многими авторами. Количество накапливаемого эфирного масла зависело от климатической зоны и условий произрастания [1]. Стандартизация сырья душицы обыкновенной проводится в соответствии с ГФ XI по содержанию эфирного масла (для цельного сырья не менее $0,10 \%$, для измельченного сырья - не менее $0,08 \%$ ). В составе масла идентифицировано более 50 компонентов, основными считаются тимол и карвакрол $[2,3]$. Основными компонентами (содержание в масле более $2 \%$ ) сибирских представителей $O$. vulgare являются сабинен $(5,3-14,4 \%), \beta$-мирцен $(2,0-5,0), 1,8$-цинеол $(2,0-6,4)$, иис- $\beta$-оцимен $(8,4-14,2)$, транс- $\beta$-оцимен $(11,0-20,1), \gamma$-терпинен $(1,0-2,7)$, кариофиллен $(8,9-13,8)$, гермакрен D (7,1-14,9), бициклогермакрен $(1,4-4,4), E, E$ - $\alpha$-фарнезен $(2,3-4,1 \%)[3,4]$. По содержанию в составе эфирного масла фенольных соединений $O$. vulgare образует четыре хемотипа. В первом отмечается высокое содержание тимола, во втором - высокое содержание карвакрола, третий имеет умеренное содержание тимола, для четвертого характерно низкое содержание фенолов, до полного отсутствия, и высокое со-

Мяделеи Марина Александровна - научный сотрудник лаборатории фитохимии, кандидат биологических наук, тел.: (383) 334-44-68, факс (383) 330-19-86, e-mail: MarinaMyadelets@yandex.ru

Васильева Ольга Юрьевна - заведующая лабораторией интродукции декоративных растений, доктор биологических наук, тел.: (383) 334-44-64, факс: (383) 330-19-86, e-mail: vasil.flowers@ rambler.ru Домрачев Дмитрий Васильевич - инженер I категории лаборатории терпеновых соединений, тел.: (383) 330-98-55, факс: (383) 330-97-52, e-mail: dmitry@ nioch.nsu.ru держание углеводородов. Общее содержание фенолов в эфирном масле, выраженное по тимолу, может составлять 75,9\% [5].

Так как O. vulgare относится к ценным в хозяйственном отношении видам растений, проводились исследования, направленные на изучение особенностей произрастания в различных экологоценотических условиях. В результате отмечена морфологическая неоднородность ценопопуляций душицы, связанная с архитектоникой генеративных побе-

\footnotetext{
* Автор, с которым следует вести переписку.
} 
гов. Так, выявлены четыре морфотипа генеративных побегов. Их соотношение в составе ценопопуляций исследованных экотопов различно и определяет как устойчивость ценопопуляций, так и их продуктивность и хозяйственную ценность продукции [6].

Для $O$. vulgare характерны цветки с лилово-розовыми венчиками, реже - с белыми [7]. Случаи изменения окраски венчика на белую в литературе не описаны. Однако причиной таких изменений может быть воздействие каких-либо факторов среды, одним из которых может послужить электромагнитное излучение. Установлено, что слабые электромагнитные излучения играют существенную роль в функционировании живой природы на различных уровнях ее организации [8]. Эволюционная адаптация выработала у всех организмов способность реагировать на изменения естественного геомагнитного поля и на сверхслабые воздействия низкочастотного и высокочастотного электромагнитного поля [9]. Возможно, что во время пребывания живого организма под воздействием электромагнитного поля у него срабатывают адаптивные механизмы уже при незначительных изменениях индукции внешнего электромагнитного излучения [10].

Хотя механизмы воздействия электромагнитого излучения на биологические системы не изучены и носят только предположительный характер [11], в литературе встречаются указания на то, что среди растений, произрастающих под ЛЭП, нередки тераты [12]. Также в процессе экспедиционных работ по поиску декоративно ценных видов и форм в различных районах Западной Сибири ранее нами были найдены под ЛЭП 0,4 кВ белоцветковые формы Erythronium sibiricum (Fischer et Meyer) Krylov (окр. пос. Каз Кемеровской области) и Pulmonaria mollis Wulfen ex Hornem. (окр. с. Заварзино).

\section{Материал и методы}

Исследованные образцы сырья (надземная часть) O. vulgare собраны в пойме р. Зырянки в Новосибирской области на границе смешанного березово-осинового леса и окультуренных территорий. Популяция находилась в радиусе 1 м от опоры ЛЭП 0,22 кВ. В эксперименте были задействованы молодые (g1) и средневозрастные (g2) генеративные растения с фиолетовыми и белыми цветками.

Эфирное масло получали из свежесобранного и измельченного сырья методом гидродистилляции [13]. Время перегонки составляло 3-4 ч. Выход эфирного масла определяли в процентах от массы свежесобранного сырья. Полученные образцы эфирного масла исследовали методом хромато-масс-спектрометрии на газовом хроматоргафе Hewlett-Packard 5890/II с квадрупольным масс-спектрометром (HP MSD 5971) в качестве детектора. Использовалась 30-метровая кварцевая колонка НР-5 (сополимер 5\%-дифенил-95\%диметилсилоксана) с внутренним диаметром 0,25 мм и толщиной пленки неподвижной фазы 0,25 мкм. Содержание компонентов вычислялось по площадям газо-хроматографических пиков без использования корректирующих коэффициентов. Качественный анализ основан на сравнении времен удерживания и полных масс-спектров с атласом спектров [14].

\section{Результаты и их обсуждение}

Для формы O. vulgare с белыми цветками, представляющей интерес не только как лекарственное, но и как декоративное растение, были характерны следующие особенности. Число генеративных побегов у рас-

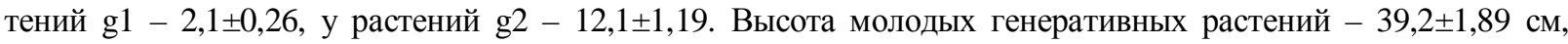

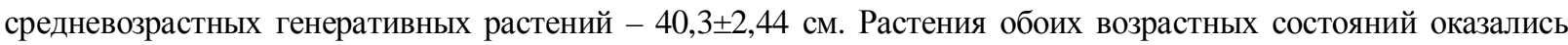
достоточно выравненными по высоте, по числу генеративных побегов наблюдалась сильная изменчивость.

Надземные органы $O$. vulgare с фиолетовыми цветками содержали $0,27 \%$ эфирного масла, с белыми - 0,08\%. Эфирное масло светло-желтого цвета, с приятным запахом. В составе масла O. vulgare с фиолетовыми цветками обнаружено 143 компонента, идентифицировано - 67. Основными компонентами (содержание свыше 2\%) являются соединения сесквитерпенового ряда - оксид кариофиллена (17,9\%), гумулен6,7-эпоксид $(2,7 \%)$, циклические монотерпеноиды - сабинен $(9,4 \%), 1,8$-цинеол $(5,5 \%)$, терпинен-4-ол $(3,3 \%)$ (табл. 1).

В составе масла $O$. vulgare с белыми цветками обнаружено 28 компонентов, идентифицировано - 20 . Основные компоненты - оксид кариофиллена (36,5 \%), изокариофиллена эпоксид В $(2,2)$, кариолан-1,9- $\beta$ диол $(4,1)$, гумулен-6,7-эпоксид $(3,9)$, н-гексакозан $(3,9)$, терпинен-4-ол $(3,8)$, гуминовый спирт $(2,6), \beta-б и-$ заболен $(2,2 \%)$. Среди компонентов масла практически отсутствуют соединения монотерпенового ряда, что может быть обусловлено рядом причин: малым количеством масла для анализа, высокой способностью к окислению и летучестью данной группы веществ. 
Состав эфирных масел Origanum vulgare

\begin{tabular}{|c|c|c|c|c|c|c|c|c|c|c|c|c|c|}
\hline \multirow[t]{5}{*}{ RI } & \multirow[t]{5}{*}{ Компоненты } & \multicolumn{12}{|c|}{ Содержание компонента } \\
\hline & & \multicolumn{4}{|c|}{ оригинальные данные } & \multicolumn{8}{|c|}{ литературные данные } \\
\hline & & \multirow{2}{*}{\multicolumn{2}{|c|}{$\begin{array}{c}\text { с фиолетовыми } \\
\text { цветками }\end{array}$}} & \multirow{2}{*}{\multicolumn{2}{|c|}{ с белыми цветками }} & \multicolumn{4}{|c|}{ Западная Сибирь [4] } & \multirow{2}{*}{\multicolumn{2}{|c|}{$\begin{array}{l}\text { Средняя Сибирь [3] } \\
\text { Красноярский. край }\end{array}$}} & \multirow{2}{*}{\multicolumn{2}{|c|}{$\begin{array}{c}\text { Восточная Сибирь [1] } \\
\text { Иркутская обл. }\end{array}$}} \\
\hline & & & & & & \multicolumn{2}{|c|}{ Новосибирская обл. } & \multicolumn{2}{|c|}{ Алтайский край } & & & & \\
\hline & & $\%$ & ppm & $\%$ & ppm & $\%$ & ppm & $\%$ & ppm & $\%$ & ppm & $\%$ & ppm \\
\hline 1 & 2 & 3 & 4 & 5 & 6 & 7 & 8 & 9 & 10 & 11 & 12 & 13 & 14 \\
\hline 926 & 3-туйен & 0,3 & 0,8 & - & - & - & - & $0,1-0,7$ & $1,1-7,7$ & 0,5 & 26,0 & - & - \\
\hline 926 & $\alpha$-туйен & - & - & - & - & 1,1 & 63,8 & - & - & - & - & - & - \\
\hline 932 & $\alpha$-пинен & 0,5 & 13,5 & - & - & 1,4 & 8,2 & $0,5-2,0$ & $5,5-22,0$ & 0,6 & 31,2 & - & - \\
\hline 947 & камфен & 0,1 & 2,7 & - & - & - & - & - & - & - & - & - & - \\
\hline 950 & 5,5-диметил-2-фуранон & $++^{1}$ & - & - & - & - & - & - & - & - & - & - & - \\
\hline 973 & сабинен & 9,4 & 253,8 & - & - & 12,1 & 701,8 & $7,5-14,4$ & $82,5-158,4$ & 5,3 & 275,6 & - & - \\
\hline 975 & $\beta$-пинен & 1,0 & 2,7 & - & - & 2,1 & 121,8 & $1,1-2,0$ & $12,1-22,0$ & 0,9 & 46,8 & - & - \\
\hline 976 & 1-октен-3-ол & - & - & - & - & 1,0 & 58,0 & $0,1-2,1$ & $1,1-23,1$ & 0,6 & 31,2 & - & - \\
\hline 988 & октан-3-он & 0,4 & 10,8 & - & - & 0,3 & 17,4 & $0,1-0,2$ & $1,1-2,2$ & 0,2 & 10,4 & - & - \\
\hline 992 & $\beta$-мирцен & 0,1 & 2,7 & - & - & 3,8 & 220,4 & $3,0-5,0$ & $33,0-55,0$ & 2,0 & 104,0 & - & - \\
\hline 996 & октан-3-ол & 0,1 & 2,7 & - & - & - & - & - & - & - & - & - & - \\
\hline 1004 & $\alpha$-фелландрен & - & - & - & - & 0,1 & 5,8 & - & - & 0,1 & 5,2 & - & - \\
\hline 1005 & $\beta$-фелландрен & - & - & - & - & - & - & 0,1 & 1,1 & 2,0 & 104,0 & 2,0 & 22,0 \\
\hline 1010 & 3-карен & - & - & - & - & - & - & 0,3 & 3,3 & - & - & - & - \\
\hline 1016 & $\alpha$-терпинен & - & - & - & - & 1,2 & 69,6 & $0,4-1,1$ & $4,4-12,1$ & 1,3 & 67,6 & - & - \\
\hline 1022 & мета-цимен & - & - & - & - & - & - & - & - & 0,5 & 26,0 & - & - \\
\hline 1024 & $n$-цимен & - & - & - & - & - & - & - & - & - & - & 1,4 & 15,4 \\
\hline 1024 & $n$-цимол & - & - & - & - & 0,9 & 52,2 & $0,3-0,4$ & $3,3-4,4$ & - & - & - & - \\
\hline 1028 & лимонен & 0,9 & 24,3 & - & - & - & - & - & - & - & - & - & - \\
\hline 1029 & 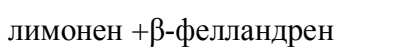 & - & - & - & - & 3,6 & 208,8 & $2,5-5,1$ & $27,5-56,1$ & - & - & - & - \\
\hline 1030 & 1,8-цинеол & 5,5 & 148,5 & - & - & 6,4 & 371,2 & $2,0-5,9$ & $22,0-64,9$ & 4,5 & 234,0 & 1,7 & 18,7 \\
\hline 1033 & фенилметанол & - & - & - & - & - & - & - & - & 0,2 & 10,4 & - & - \\
\hline 1039 & ичис- $\beta$-оцимен & 8,1 & 218,7 & - & - & - & - & - & - & - & - & - & - \\
\hline 1039 & изис- $\beta$-оцимен & - & - & & - & 9,8 & 568,4 & $8,4-14,2$ & $92,4-156,2$ & 10,9 & 566,8 & - & - \\
\hline 1048 & транс- $\beta$-оцимен & 0,3 & 8,1 & - & - & 15,5 & 89,9 & $13,8-0,1$ & $151,8-221,1$ & 11,0 & 572,0 & - & - \\
\hline 1058 & $\gamma$-терпинен & 0,1 & 2,7 & - & - & 2,5 & 145,0 & $1,0-2,7$ & $11,0-29,7$ & 2,3 & 119,6 & - & - \\
\hline 1066 & транс-сабиненгидрат & 0,2 & 5,4 & - & - & 1,9 & 110,2 & $0,1-0,2$ & $1,1-2,2$ & 2,3 & 119,6 & - & - \\
\hline 1072 & транс-фуранолиналол оксид & 0,2 & 5,4 & - & - & - & - & - & - & - & - & - & - \\
\hline 1089 & цис-фуранолиналол оксид & 0,2 & 5,4 & - & - & - & - & - & - & - & - & - & - \\
\hline 1089 & терпинолен & - & - & - & - & 0,4 & 232,0 & $0,3-0,8$ & $3,3-8,8$ & 0,6 & 31,2 & - & - \\
\hline
\end{tabular}


Продолжение таблищь

\begin{tabular}{|c|c|c|c|c|c|c|c|c|c|c|c|c|c|}
\hline 1 & 2 & 3 & 4 & 5 & 6 & 7 & 8 & 9 & 10 & 11 & 12 & 13 & 14 \\
\hline 1095 & изис-сабиненгидрат & - & - & - & - & 1,6 & 92,8 & 0,1 & 1,1 & 0,3 & 15,6 & - & - \\
\hline 1098 & розфуран & 0,3 & 8,1 & - & - & - & - & - & - & - & - & - & - \\
\hline 1100 & линалоол & 1,2 & 32,4 & - & - & 2,1 & 121,8 & $0,4-1,4$ & $4,4-15,4$ & 2,5 & 130,0 & 2,0 & 22,0 \\
\hline 1121 & ичис-пара-мент-2-ен-1-ол & 0,3 & 8,1 & - & - & - & - & - & - & - & - & - & - \\
\hline 1121 & $\begin{array}{l}\text { 4-гидрокси-4-метил-циклогекс- } \\
\text { 2-енон }\end{array}$ & 0,3 & 8,1 & - & - & - & - & - & - & - & - & - & - \\
\hline 1128 & $\begin{array}{l}\text { (4Е,6Z)-2,6-диметил-2,4,6- } \\
\text { октатриен }\end{array}$ & - & - & - & - & 0,9 & 52,2 & $1,0-2,0$ & $11,0-22,0$ & - & - & - & - \\
\hline 1130 & 2,6-диметил-1,3,5,7-октатетраен & - & - & - & - & - & - & - & - & 0,1 & 5,2 & - & - \\
\hline 1156 & сабина кетон & 0,7 & 18,9 & - & - & - & - & - & - & - & - & - & - \\
\hline 1167 & $\delta$-терпинеол & 0,1 & 2,7 & - & - & - & - & - & - & 0,1 & 5,2 & - & - \\
\hline 1140 & ичис-сабинол & 0,3 & 8,1 & - & - & - & - & - & - & - & - & - & - \\
\hline 1144 & камфора & - & - & - & - & - & - & - & - & 0,1 & 5,2 & - & - \\
\hline 1176 & терпинен-4-ол & 3,3 & 89,1 & 3,8 & 30,4 & 0,8 & 46,4 & $0,1-0,7$ & $1,1-7,7$ & 2,6 & 135,2 & - & - \\
\hline 1184 & мета-цимен-8-ол & 1,2 & 32,4 & 1,0 & 8,0 & - & - & - & - & - & - & - & - \\
\hline 1186 & пара-цимен-8-ол & - & - & - & - & - & - & - & - & - & & 0,7 & 7,7 \\
\hline 1190 & $\alpha$-терпинеол & 1,3 & 35,1 & 0,3 & 2,4 & 1,5 & 87,0 & $0,1-0,6$ & $1,1-6,6$ & 4,7 & 244,4 & 0,5 & 5,5 \\
\hline 1195 & ųис-пиперитол & - & - & - & - & - & - & - & - & - & - & 0,5 & 5,5 \\
\hline 1224 & 2-экзо-гидрокси-1,8-цинеол & 0,1 & 2,7 & - & - & - & - & - & - & - & - & - & - \\
\hline 1241 & куминовый альдегид & 0,3 & 8,1 & 0,4 & 3,2 & - & - & - & - & - & - & - & - \\
\hline 1276 & фелландраль & 0,3 & 8,1 & - & - & - & - & - & - & - & - & - & - \\
\hline 1288 & дигидроэдулан & 0,6 & 16,2 & - & - & 0,1 & 5,8 & $0,1-0,2$ & $1,1-2,2$ & 0,3 & 15,6 & 0,5 & 5,5 \\
\hline 1291 & тимол & - & - & - & - & 0,1 & 5,8 & 0,2 & 2,2 & 0,1 & 5,2 & 1,1 & 12,1 \\
\hline 1293 & куминовый спирт & 0,6 & 16,2 & 2,6 & 20,8 & - & - & - & - & - & - & - & - \\
\hline 1302 & карвакрол & - & - & - & - & - & - & - & - & - & - & 0,3 & 3,3 \\
\hline 1335 & бициклоэлемен & - & - & - & - & 0,5 & 29,0 & $0,4-0,9$ & $4,4-9,9$ & - & - & - & - \\
\hline 1377 & $\alpha$-копаен & 0,1 & 2,7 & - & - & - & - & - & - & 0,2 & 10,4 & - & - \\
\hline 1385 & $\beta$-бурбонен & 0,8 & 21,6 & 0,7 & 5,6 & 0,5 & 29,0 & $0,4-0,6$ & $4,4-6,6$ & 0,6 & 31,2 & 0,2 & 2,2 \\
\hline 1392 & $\beta$-элемен & 0,4 & 10,8 & - & - & 0,2 & 11,6 & $0,2-0,6$ & $2,2-6,6$ & 0,2 & 10,4 & - & - \\
\hline 1401 & $\beta$-лонгипинен & 0,2 & 5,4 & - & - & - & - & - & - & - & - & - & - \\
\hline 1418 & кариофиллен & - & - & & - & 9,1 & 527,8 & $8,9-13,8$ & $97,9-151,8$ & 13,4 & 696,8 & - & - \\
\hline 1426 & карвон гидрат & 0,1 & 2,7 & - & - & - & - & - & - & - & - & - & - \\
\hline 1426 & эпи-бициклосесквифелландрен & - & - & - & - & - & - & $0,2-0,5$ & $2,2-5,5$ & - & - & - & - \\
\hline 1432 & $\beta$-копаен & 0,1 & 2,7 & - & - & - & - & - & - & 0,5 & 26,0 & - & - \\
\hline 1452 & транс-мурола-3,5-диен & - & - & - & - & - & - & - & - & 0,1 & 5,2 & - & - \\
\hline
\end{tabular}


Продолжение таблиць

\begin{tabular}{|c|c|c|c|c|c|c|c|c|c|c|c|c|c|}
\hline 1 & 2 & 3 & 4 & 5 & 6 & 7 & 8 & 9 & 10 & 11 & 12 & 13 & 14 \\
\hline 1456 & гумулен & 0,1 & 2,7 & - & - & 1,5 & 87,0 & $1,4-2,5$ & $15,4-27,5$ & 2,3 & 119,6 & 0,7 & 7,7 \\
\hline 1460 & аллоаромадендрен & - & - & - & - & 0,4 & 23,2 & $0,3-0,5$ & $3,3-5,5$ & 0,6 & 31,2 & - & - \\
\hline 1480 & $\gamma$-мууролен & - & - & - & - & - & - & - & - & 0,4 & 20,8 & - & - \\
\hline 1480 & гермакрен D & - & - & - & - & 7,1 & 411,8 & $7,8-14,9$ & $85,8-163,9$ & 10,4 & 540,8 & - & - \\
\hline 1494 & бициклогермакрен & - & - & - & - & 2,0 & 116,0 & $1,4-4,4$ & $15,4-48,4$ & 2,3 & 119,6 & - & - \\
\hline 1494 & бициклосесквифелландрен & - & - & - & - & - & - & - & - & 0,3 & 15,6 & - & - \\
\hline 1496 & $\alpha$-фарнезен & - & - & - & - & - & - & - & - & 0,3 & 15,6 & - & - \\
\hline 1498 & $\alpha$-муролен & - & - & - & - & 0,2 & 11,6 & $0,1-0,2$ & $1,1-2,2$ & 0,5 & 26,0 & - & - \\
\hline 1511 & $\beta$-бизаболен & 0,6 & 16,2 & 2,2 & 17,6 & - & - & - & - & 1,3 & 67,6 & 2,8 & 30,8 \\
\hline 1517 & $\gamma$-кадинен & 0,1 & 2,7 & - & - & 0,2 & 11,6 & $0,5-0,9$ & $5,5-9,9$ & 0,6 & 31,2 & 0,3 & 3,3 \\
\hline 1524 & транс-каламенен & 0,1 & 2,7 & - & - & 0,5 & 29,0 & - & - & - & - & - & - \\
\hline 1523 & $\delta$-кадинен & - & - & - & - & - & - & $0,5-0,9$ & $5,5-9,9$ & 2,1 & 109,2 & - & - \\
\hline 1536 & транс-кадина-1,4-диен & - & - & - & - & - & - & - & - & 0,1 & 5,2 & - & - \\
\hline 1541 & $\alpha$-кадинен & - & - & - & - & - & - & - & - & 0,2 & 10,4 & - & - \\
\hline 1560 & изокариофиллена эпоксид В & 1,1 & 29,7 & 2,1 & 16,8 & - & - & - & - & - & - & - & - \\
\hline 1602 & элемол & 0,4 & 10,8 & 0,9 & 7,2 & - & - & - & - & - & - & - & - \\
\hline 1574 & гермакрен D-4-ол & - & - & - & - & 1,0 & 58,0 & - & - & - & - & - & - \\
\hline 1577 & 4-гидрокси-гермакра-1,5-диен & - & - & - & - & - & - & - & - & 0,1 & 5,2 & - & - \\
\hline 1580 & спатуленол & 1,2 & 32,4 & - & - & 0,6 & 34,8 & $0,1-0,2$ & $1,1-2,2$ & 0,4 & 20,8 & - & - \\
\hline 1581 & кариофиллен- $\alpha$-оксид & - & - & - & - & 1,1 & 63,8 & $0,1-0,6$ & $1,1-2,2$ & 1,3 & 67,6 & - & - \\
\hline 1586 & оксид кариофиллена & 17,9 & 483,3 & 36,5 & 292,0 & - & - & - & - & - & - & 27,2 & 299,2 \\
\hline 1593 & виридифлорол & 0,3 & 8,1 & - & - & - & - & - & - & - & - & 0,6 & 6,6 \\
\hline 1607 & $E, E$ - $\alpha$-фарнезен & - & - & - & - & 2,9 & 168,2 & $3,0-4,1$ & $33,0-45,1$ & 2,3 & 119,6 & - & - \\
\hline 1612 & гумулен-6,7-эпоксид & 2,7 & 72,9 & 3,9 & 312,0 & - & - & - & - & - & - & - & - \\
\hline 1633 & $\gamma$-эвдесмол & 0,4 & 10,8 & 0,6 & 4,8 & - & - & - & - & - & - & - & - \\
\hline 1643 & Т-кадинол+ Т-муролол & 0,5 & 13,5 & 0,5 & 4,0 & 0,2 & 11,6 & $0,3-0,4$ & $3,3-4,4$ & 1,2 & 62,4 & 0,3 & 3,3 \\
\hline 1651 & $\beta$-эвдесмол & - & - & 0,5 & 4,0 & - & - & - & - & - & - & - & - \\
\hline 1658 & $\alpha$-кадинол & 1,1 & 29,7 & 1,5 & 12,0 & 0,2 & 11,6 & - & - & 1,2 & 62,4 & - & - \\
\hline 1662 & $\begin{array}{l}\text { (3Z)-кариофилла-3,8(13)-диен- } \\
5 \beta \text {-ол }\end{array}$ & 0,5 & 13,5 & 1,5 & 12,0 & - & - & - & - & - & - & - & - \\
\hline 1683 & $\begin{array}{l}\text { 13-нор-8-оксо-(1R, 4S, 5R, 9S)- } \\
\text { изокариофиллен оксид В }\end{array}$ & 0,4 & 10,8 & 0,9 & 7,2 & - & - & - & - & - & - & - & - \\
\hline 1688 & эвдесма-4(15), 7-диен-1 $\beta$-ол & 0,3 & 8,1 & - & - & - & - & - & - & - & - & - & - \\
\hline 1730 & $\begin{array}{l}\text { гумулен-2,3;6,7-диэпоксид (2S*, 3S*, } \\
\left.6 \mathrm{R}^{*}, 7 \mathrm{R}^{*}, 9 \mathrm{E}\right)\end{array}$ & 0,3 & 8,1 & 1,1 & 8,8 & - & - & - & - & - & - & - & - \\
\hline
\end{tabular}




\begin{tabular}{|c|c|c|c|c|c|c|c|c|c|c|c|c|c|}
\hline 1 & 2 & 3 & 4 & 5 & 6 & 7 & 8 & 9 & 10 & 11 & 12 & 13 & 14 \\
\hline 1760 & циклоколоренон & 0,2 & 5,4 & - & - & - & - & - & - & - & - & - & - \\
\hline 1813 & кариолан-1,9- $\beta$-диол & - & - & 4,1 & 32,8 & - & - & - & - & - & - & - & - \\
\hline $1^{2}$ & амилвинилкарбинол & - & - & - & - & - & - & - & - & - & - & 0,5 & 5,5 \\
\hline 5 & транс-2-циклогексен-1-ол & - & - & - & - & - & - & - & - & - & - & 0,5 & 5,5 \\
\hline 6 & ицс-2-циклогексен-1-ол & - & - & - & - & - & - & - & - & - & - & 0,5 & 5,5 \\
\hline 21 & транс-лонгипинокарвеол & - & - & - & - & - & - & - & - & - & - & 1,8 & 19,8 \\
\hline 30 & $\begin{array}{l}\text { 12-оксабицикло[9.1.0]додека-3,7- } \\
\text { диен, 1,5,5,8-тетраметил-12- } \\
\text { оксабицикло[9.1.0]додека-3,7-диен }\end{array}$ & - & - & - & - & - & - & - & - & - & - & 3,6 & 39,6 \\
\hline 31 & $\begin{array}{l}\text { трицикло[5.2.2.0(1, 6)]ундекан-3- } \\
\text { ол }\end{array}$ & - & - & - & - & - & - & - & - & - & - & 2,2 & 24,2 \\
\hline 34 & $\begin{array}{l}\text { 4,4-диметил-тетрацикло } \\
{[6.3 .2 .0(2,5) .0(1,8)] \text { тридекан-9-ол }}\end{array}$ & - & - & - & - & - & - & - & - & - & - & 0,7 & 7,7 \\
\hline 36 & аромадендрен-2-оксид & - & - & - & - & - & - & - & - & - & - & 0,7 & 7,7 \\
\hline 37 & изоаромадендрен эпоксид & - & - & - & - & - & - & - & - & - & - & 0,9 & 9,9 \\
\hline 38 & диэпицедрен-1-оксид & - & - & - & - & - & - & - & - & - & - & 0,5 & 5,5 \\
\hline 39 & $\begin{array}{l}\text { 3-изопропил-6,7-диметилтрицикло } \\
{[4.4 .0 .0(2,8)] \text { декано-9,10-диол }}\end{array}$ & - & - & - & - & - & - & - & - & - & - & 2,0 & 22,0 \\
\hline 40 & $\begin{array}{l}\text { (1,5,5,8-тетраметилбицикло } \\
\text { [4.2.1]нон-9-ил)-уксусная кислота }\end{array}$ & - & - & - & - & - & - & - & - & - & - & 0,5 & 5,5 \\
\hline 42 & $\begin{array}{l}\text { [8S]-спиро[трицикло[4.4.0.0(5,9)] } \\
\text { декан-10,2'-оксиран]-1-метил-4- } \\
\text { изопропил-7,8-дигидрокси }\end{array}$ & - & - & - & - & - & - & - & - & - & - & 0,2 & 2,2 \\
\hline
\end{tabular}

Примечания: ${ }^{1}$ содержание соответствующего компонента не превышает $0,05 \% ;{ }^{2}$ порядковый номер компонента. 
В исследованных образцах не обнаружены такие главные компоненты эфирного масла O. vulgare, как фенолы тимол и карвакрол, известные по литературным данным,. Следовательно, по составу изученные образцы эфирных масел относятся к хемотипу, не содержащему фенольных соединений. Отсутствие различий компонентного состава эфирного масла $O$. vulgare, полученного из свежесобранного и воздушно сухого сырья [4], позволило сравнить исследуемые образцы с образцами, полученными из сырья других регионов Сибири (табл. 1). Сравнение показывает сходство между изученными образцами и образцами дикорастущих преставителей, собранных на территории Западной Сибири (Алтайский край, Новосибирская область), где основные компоненты (\%) - сабинен (12,1-17,7), ß-мирцен $(3,3-4,5), 1,8$-цинеол (4,6$6,4)$, иис-ß-оцимен $(9,8-11,6)$, транс-ß-оцимен $(15,5-17,8)$, кариофиллен $(9,1-10,6)$, гермакрен D $(7,1-8,9)$,

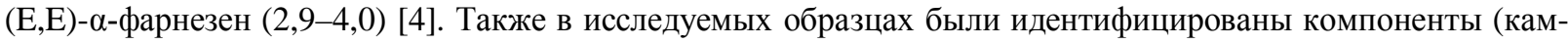
фен, розфуран, фелландрал, ß-лонгипенен, элемол и др.), не указанные для ранее изученных образцов других сибирских регионов $[1,3,4]$. Анализируя имеющиеся данные о составе масел сибирских образцов O. vulgare и собственные результаты исследования, следует отметить, что общими компонентами являются $\alpha$-терпинеол $(0,1-4,7 \%), \beta$-бурбонен $(0,2-0,8)$, кариофиллен $(8,9-13,8)$ или его оксид $(0,6-36,5)$, Т-кадинол и Т-муролол $(0,2-1,2 \%)$

В отличие от растений с фиолетовыми цветками, в образце масла белой формы обнаружено в пять раз меньше компонентов. При сравнении общих для них компонентов видно, что их процентное содержание в эфирном масле белой формы зачастую в два раза выше. Напротив, сопоставление абсолютных количеств компонентов (ppm) указавыет, что все компоненты (за исключением ß-бизаболена и гумулен-2,3,6,7диэпоксида $\left(2 \mathrm{~S}^{*}, 3 \mathrm{~S}^{*}, 6 \mathrm{R}^{*}, 7 \mathrm{R}^{*}, 9 \mathrm{E}\right)$ ) в большем количестве содержатся в масле образца с фиолетовыми цветками. В составе эфирного масла изученных образцов O. vulgare преобладают сесквитерпены. Сопоставляя процентное содержание доминирующих компонентов $O$. vulgare с фиолетовыми и белыми цветками, следует отметить, что оксида кариофиллена в масле белой формы содержится в 2 раза больше. Так как кариофиллен в образцах не обнаружен, можно предположить, что оксид кариофиллена является нативным компонентом.

\section{Заключение}

Таким образом, принципиальных различий в компонентном составе эфирных масел исследованных нами образцов $O$. vulgare с фиолетовыми и белыми цветками не выявлено. Разница основных компонентов изученных образцов эфирных масел заключается в их количественных соотношениях.

\section{Список литературь}

1. Мирович В.М., Коненкина Т.А., Федосеева Г.М., Головных Н.Н. Исследование качественного состава эфирного масла душицы обыкновенной, произрастающей в Восточной Сибири // Химия растительного сырья. 2008. №2. С. 61-64.

2. Растительные ресурсы СССР: цветковые растения, их химический состав; использование. Семейства Hippuridaceae - Lobeliaceae. СПб., 1991. С. 59-61.

3. Алякин А.А., Ефремов А.А., Качин С.В., Данилова О.О. Фракционный состав эфирного масла душицы обыкновенной Красноярского края // Химия растительного сырья. 2010. №1. С. 99-104.

4. Казаринова Н.В., Ткаченко К.Г., Музыченко Л.М., Сафонова Н.Г., Ткачев А.В., Королюк Е.А. Компонентный состав и антибиотическая активность эфирного масла Origanum vulgare L., произрастающей в некоторых регионах Западной Сибири // Растительные ресурсы. 2002, Т. 38, вып. 2. С. 99-103.

5. Werker E., Putievky E., Ravid U. The essential oils and glandular hairs in different chemotypes of Origanum vulgare L. // Ann. Bot. 1985. Vol. 55, N6. Pp. 793-801.

6. Гончаров В.Е. Эколого-ценотический анализ пространственно-временной организации ценопопуляций душицы обыкновенной как основа рациональной эксплуатации ее ресурсов в Татарстане : дис. ... канд. биол. наук. Казань, 2003. 129 с.

7. Флора Сибири. Т. 11. / под ред. Л.И. Малышева. Новосибирск, 1997. 188 с.

8. Дубров А.П. Геомагнитное поле и жизнь. Л., 1974. 176 с.

9. Акоев И.Г. Биологические эффекты электромагнитных полей // Вопросы их использования и нормирования : сб. науч. трудов. Пущино, 1988. С. 129-135.

10. Сарокваша О.Ю. Воздействие электромагнитного излучения ЛЭП-110 кВ на общую численность микроорганизмов в почве // Успехи современного естествознания. 2006. №3. С. 46.

11. Фролов Ю.П., Серых М.М., Инюшкин А.Н. и др. Управление биологическими системами. Организменный уровень. Самара, 2001. 318 с. 
12. Пленник Р.Я. Стратегии биоморфологической микроэволюции полиморфного вида Medicago falcata L. в Cибири. Новосибирск, 2002. 94 с.

13. Государственная Фармакопея СССР. 11-е изд-е. М., 1990. Вып. 2. 400 с.

14. Ткачев А.В. Исследование летучих веществ растений. Новосибирск, 2008. 969 с.

Поступило в редакцию 19 декабря 20112.

Myadelets M.A. ${ }^{{ }^{*}}$, Vasileva O.Ju. ${ }^{2}$, Domrachev D.V. ${ }^{l}$ RESEARCH OF A CHEMICAL COMPOUND OF ESSENTIAL OILS ORIGANUM VULGARE L. WITH VARIOUS PAINTING FLOWER

${ }^{1}$ Central Siberian Botanical Garden SB RAS, st. Zolotodolinskaia, 101, Novosibirsk, 630090 (Russia),

e-mail: MarinaMyadelets@yandex.ru

${ }^{2}$ N.N. Vorozhtsov Novosibirsk Institute Of Organic Chemistry of the Siberian Branch of Russian Academy of Science,

pr. Lavrentieva, 9, Novosibirsk, 630090 (Russia)

By method of chromatography-mass-spectrometry it is carried out comparative research of a chemical composition of essential oils Origanum vulgare L. with white and violet flower growing near to an electric main. In structure of essential oil $O$. vulgare with violet flower 143 components (identified 67), with white - 28 (identified 20) are revealed. Percentage of the general for samples of components frequently twice above in essential oil of white form $O$. vulgare. The investigated samples of essential oil concern to chemical type not containing phenolic connections.

Keywords: Origanum vulgare L., essential oils, chromatography-mass-spectrometry, electromagnetic radiation.

\section{References}

1. Mirovich V.M., Konenkina T.A., Fedoseeva G.M., Golovnykh N.N. Khimiia rastitel'nogo syr'ia, 2008, no. 2, pp. 61-64. (in Russ.).

2. Rastitel'nye resursy SSSR: tsvetkovye rasteniia, ikh khimicheskii sostav; ispol'zovanie. Semeistva Hippuridaceae Lobeliaceae. [Plant Resources of the USSR: the flowering plants, their chemical composition, the use of. Families of Hippuridaceae - Lobeliaceae]. Saint Petersburg, 1991, pp. 59-61. (in Russ.).

3. Aliakin A.A., Efremov A.A., Kachin S.V., Danilova O.O. Khimiia rastitel'nogo syr'ia, 2010, no. 1, pp. 99-104. (in Russ.).

4. Kazarinova N.V., Tkachenko K.G., Muzychenko L.M., Safonova N.G., Tkachev A.V., Koroliuk E.A. Rastitel'nye resursy, 2002, vol. 38, no. 2, pp. 99-103. (in Russ.).

5. Werker E., Putievky E., Ravid U. Ann. Bot.,1985, vol. 55, no. 6, pp. 793-801.

6. Goncharov V.E. Ekologo-tsenoticheskii analiz prostranstvenno-vremennoi organizatsii tsenopopuliatsii dushitsy obyknovennoi, kak osnova ratsional'noi ekspluatatsii ee resursov v Tatarstane : dis. ... kand. biol. nauk. [Ecological and coenotic analysis of the spatial and temporal organization of populations Oregano, as the basis of a rational exploitation of its resources in Tatarstan: Ph.D. thesis]. Kazan, 2003, 129 p. (in Russ.).

7. Flora Sibiri. T. 11. / pod red. L.I. Malysheva. [Flora of Siberia. Vol. 11. / Ed. L.I. Malyshev.]. Novosibirsk, 1997, 188 p. (in Russ.).

8. Dubrov A.P. Geomagnitnoe pole i zhizn'. [Geomagnetic Field and Life]. Leningrad, 1974, 176 p. (in Russ.).

9. Akoev I.G. Biologicheskie effekty elektromagnitnykh polei. Voprosy ikh ispol'zovaniia i normirovaniia: sb. nauch. trudov. [Biological effects of electromagnetic fields. About their use and regulation: a collection of scientific papers]. Pushchino, 1988, pp. 129-135. (in Russ.).

10. Sarokvasha O.Iu. Uspekhi sovremennogo estestvoznaniia, 2006, no. 3, pp. 46. (in Russ.).

11. Frolov Iu.P., Serykh M.M., Iniushkin A.N. et al. Upravlenie biologicheskimi sistemami. Organizmennyi uroven'. [Management of biological systems. Organismal level]. Samara, 2001, 318 p. (in Russ.).

12. Plennik R.Ia. Strategii biomorfologicheskoi mikroevoliutsii polimorfnogo vida Medicago falcata L. v Sibiri. [Strategy Biomorphological microevolution polymorphic species Medicago falcata L. in Siberia]. Novosibirsk, 2002, 94 p. (in Russ.).

13. Gosudarstvennaia Farmakopeia SSSR. 11-e izd. [State Pharmacopoeia of the USSR. 11th ed.]. Moscow, 1990, no. 2, 400 p. (in Russ.).

14. Tkachev A.V. Issledovanie letuchikh veshchestv rastenii. [The study of plant volatiles]. Novosibirsk, 2008, 969 p. (in Russ.).

\footnotetext{
* Corresponding author.
} 